\title{
RADIOTERAPI KANKER CERVIX DENGAN LINEAR ACCELERATOR (LINAC)
}

Winarno $^{1,2}$, Veren Audia Nurmansya*1, Zakiyatul Miskiyah ${ }^{1}$

${ }^{1}$ Departemen Fisika Fakultas Sains dan Teknologi Universitas Airlangga

${ }^{2}$ Biophysics and Medical Physics Research Group, Fakultas sains dan Teknologi, Universitas

Airlangga

e-mail: ${ }^{* 1}$ veren.audia.nurmansya-2017@ fst.unair.ac.id, ${ }^{2}$ zakiyatul.miskiyah-

2017@fst.unair.ac.id,winarno@fst.unair.ac.id

\begin{abstract}
Abstrak
Kanker serviks merupakan salah satu kanker mematikan yang sering terjadi di Indonesia. Pada tahun 2019, Kementerian Kesehatan mencatat kanker serviks menempati peringkat kedua untuk jenis kanker yang paling banyak ditemui setelah kanker payudara. Setiap tahunnya, ada sekitar 40.000 kasus baru kanker serviks yang terdeteksi pada perempuan Indonesia. Upaya dalam menyembuhkannya melalui radioterapi dengan radiasi pengion yang untuk mematikan sel kanker. Sumber yang digunakan adalah sinar X atau foton. Salah satu jenis pesawat radioterapi eksternal adalah Akselerator Linear (Linac). Dalam melakukan kalibrasi alat - alat radioterapi khususnya LINAC dan dalam melakukan treatment planning system (TPS) pada kanker memerlukan seorang fisikawan medis. Observasi dilakukan dengan tahapan orientasi, observasi langsung, hingga konsultasi dan diskusi. Peran fisikawan medis meliputi perencanaan TPS, simulasi pada kanker pasien, pembuatan blok untuk melindungi organ sehat, perhitungan dosis serta melakukan penyinaran. Pentingnya peran seorang fisikawan medis dalam proses radioterapi untuk mengobati kanker serviks.
\end{abstract}

Kata kunci— kanker serviks, LINAC , fisikawan medis

\begin{abstract}
Cervix cancer is a deadly cancer that often occurs in Indonesia. In 2019, the Ministry of Health recorded cervical cancer as the second most common type of cancer after breast cancer. Every year, there are around 40,000 new cases of cervical cancer that are detected in Indonesian women. Efforts in curing it through radiotherapy with ionizing radiation to kill cancer cells. The source used is X-rays or photons. One type of external radiotherapy plane is the Linear Accelerator (Linac). In calibrating radiotherapy devices, especially LINAC and in conducting a treatment planning system (TPS) in cancer, a medical physicist is required. Observation was carried out with stages of orientation, direct observation, also consultation and discussion. The role of medical physicists includes planning TPS, simulating cancer patients, making blocks to protect healthy organs, calculating doses and conducting irradiation. The importance of the role of a medical physicist in the process of radiotherapy to treat cervix cancer.
\end{abstract}

Keywords-Cervix cancer, LINAC, medical physicist 


\section{PENDAHULUAN}

Fisika medis merupakan suatu disiplin ilmu yang mengenal, mempelajari serta menganalisis berbagai faktor dan gejala fisik paparan radiasi yang berpengaruh terhadap manusia dan lingkungan. Dalam dunia medis, para ahli terdorong untuk terus menggali ilmu pengetahuan dan teknologi demi mengentaskan permasalahan kesehatan yangmembutuhkan penanganan serius dengan berbagai peralatan medis. Salah satu teknologi yang dibutuhkan yaitu Radioterapi, dimana dalam pemanfaatannya diperlukan suatu sistem pengaturan untuk dapat memenuhi perencanaan terapi.

Radioterapi merupakan suatu tindakan pengobatan medis yang dilakukan dengan menggunakan radiasi pengion yang untuk mematikan sel kanker yang di derita oleh pasien dengan melakukan terapi pada kerusakan sel kanker semaksimal mungkin. Dalam tindakan pengobatan kanker ini bersifat tertutup. Radioterapi eksternal merupakan bentuk pengobatan radiasi dengan sumber radiasi mempunyai jarak dengan target yang dituju atau berada diluar tubuh. Sumber yang digunakan adalah sinar $\mathrm{X}$ atau foton. Salah satu jenis pesawat radioterapi eksternal adalah Akselerator Linear (Linac).

Salah satu instrumen yang digunakan dalam radioterapi adalah Akselerator Linier (LINAC). LINAC ini merupakan instrumen yang menggunakan gelombang elektromagnetik dengan frekuensi tinggi untuk mempercepat partikel bermuatan seperti elektron. Elektron berenergi tinggi tersebut bisa digunakan untuk mengobati tumor pada kedalaman yang dangkal, atau electron tersebut dikenakan pada target sehingga menghasilkan foton untuk mengobati tumor dengan kedalaman yang cukup jauh.

LINAC dapat memproduksi foton dan elektron dalam berbagai tingkatan energi. Energi yang digunakan untuk foton dan elektron berorde $\mathrm{MeV}$. Keluaran pada setiap energi memiliki karakteristik yang berbeda dengan tujuan penggunaan yang berbeda. Mekanisme keluaran foton dan elektron juga merupakan pertimbangan dalam menentukan penggunaan nilai energi baik foton maupunelektron. Sehingga, LINAC sangat dianjurkan untuk mengobati kanker terutama kanker cervix.

Menurut WHO, kanker cervixmerupakan jenis kanker nomor empat yang paling sering menyerang wanita. Pengamatan WHO juga menghasilkan kesimpulan bahwa angka kejadian kanker cervix lebih besar di negara-negara berkembang daripada di negaranegaramaju. Pada tahun 2019, Kementerian
Kesehatan mencatat kanker cervix menempati peringkat kedua untuk jenis kanker yang paling banyak ditemui setelah kanker payudara. Setiap tahunnya, ada sekitar 40.000 kasus baru kanker cervix yang terdeteksi pada perempuan Indonesia.Tingginya tingkat kematian pada pengidap kanker cervix diduga karena keterlambatan diagnosis. Banyak pengidap kanker cervix yang sulit mendeteksi gejala kanker cervix itu sendiri.

Pada jurnal ini akan dijelaskan tetang perencanaan pengobatan (treatment planning system) pada kanker cervix menggunakan Akselerator Linier (LINAC) di RSUD Dr. Soetomo Surabaya. Dan bertujuan agar kita mengetahui apa saja peran Fisikawan Medis dalam pengobatan kanker Cervix menggunakan LINAC sekaligus juga dapat member wawasan pada pembaca tentang Radioterapi.

\section{RADIOTERAPI CA-CERVIX}

Fisikawan Medis sangat berperan dalam proses Radioterpi Ca-Cervix menggunakan LINAC. Mulai dari planning, hingga pelaksanaan Radioterapi.

\subsection{Radioterapi}

Radioterapi telah diterima sebagai sebuah modalitas penting pada pengobatan penyakit kanker tidak lama setelah ditemukan sinar $\mathrm{X}$ pada akhir abad XIX disamping modalitas lain seprti pembedahan dan kemoterapi. Modalitas ini berkembang dengan pesat mengikuti perkembangan teknologi pada umumnya. Radiasi eksterna yang merupakan metode pemberian radiasi konvensiaonal telah berubah dengan kemampuan meningkatnya tegangan yang dihasilkan oleh sistem generator penghasil foton. Semakin tinggi tegangan yang dihasilkan semakin optimal pula hasil pengobatan, yakni diperoleh kematian jaringan tumor sebanyak - banyaknya tetapi kerusakan jaringan sehat sekitarnya minimal. Radiasi eksterna diawali dengan penggunaa anode statis yang menghasilkan tegangan sebanyak 10 kilo Volt, dan sekarang dengan teknologi akselarator dapat dihasilkan tegangan tinggi dlaam penggunaan untuk kesehatan sampai dengan 15 Mega Volt di samping elektron. Di negara maju akselarator untuk kesehatan

JBP Vol.23, No.02, Desember 2021- Winarno, Veren Audia Nurmansya, Zakiyatul Miskiyah 
juga telah merambah penggunaan proton serta partikel berat lainnya.

Tahun 1970, penggunaan linier akselerator energi tinggi mempunyai multi energi berkas elektron dan foton, yaitu pada energi radiasi dengan elektron untuk keperluan radioterapi adalah berkisar 4-22 $\mathrm{MeV}$ dan untuk energi radiasi dengan foton adalah 6- $18 \mathrm{MV}$. Sifat dari radiasi pengion dapat merusak jaringan, maka diusahakan dosis radiasi yang diberikan pada sel tumor harus terdistribusi secara merata atau homogen sesuai dengan aturan International Commision on Radiation Unit (ICRU) yaitu dosis maksimum dalam rentang $95 \%-100 \%$ (Syam, 2012).

\subsubsection{Tujuan dari adanya radiasi}

- Menyembuhkan atau mengecilkan kanker pada stadium dini Radiasi digunakan untuk membuat kanker mengecil atau hilang sama sekali. Untuk kasus kanker lain, bisa digunakan untuk mengecilkan tumor sebelum operasi (pre-operative therapy) atau setelah operasi yang tujuannya untuk menjaga agar kanker tidak kambuh (adjuvant therapy). Terapi ini dapat juga dilakukan bersamaan dengan chemotherapy.

- Mencegah agar kanker tidak muncul di area lain. Apabila suatu jenis kanker diketahui menyebar ke area tertentu, kemungkinan akan dilakukan treatment untuk mencegah agar sel tersebut tidak berubah menjadi tumor. Sebagai contoh, pasien dengan beberapa type kanker paru-paru, mungkin akan menerima prophylactic (preventive) radiasi di kepala sebab tipe kanker ini sering menyebar keotak.

- Mengobati gejala-gejala pada kanker stadium lanjut. Beberapa kanker mungkin telah menyebar jauh dari perkiraan pengobatan. Tetapi hal ini bukan berarti kanker tersebut tidak bisa diobati agar pasien merasa lebih baik. Radiasi bisa untuk membebaskan dari rasa sakit, masalah pada pemasukkan makanan, bernafas atau pada usus besar, yang semua itu disebabkan oleh kanker yang sudah pada stadium lanjut.Carainibiasadinamakanpalliativer adiation.

\subsubsection{Prinsip Dasar Radioterapi}

Prinsip Radioterapi Radioterapi adalah suatu jenis pengobatan yang menggunakan atau memanfaatkan radiasi pengion (sinar-X, dan sinar Gamma) dan partikel lainnya untuk mematikan sel-sel kanker tanpa akibat fatal pada jaringan sehat disekitarnya. Prinsip radioterapi adalah memberikan dosis radiasi yang mematikan tumor pada daerah yang telah ditentukan (volume target) sedangkan jaringan normal sekitarnya mendapat dosis seminimal mungkin. Hal ini sangat ditunjang dengan kemajuan teknologi dari alat-alat radioterapi dan kemajuan dari komputer. Perkembangan teknologi di dunia kedokteran tidak dapat dipungkiri telah membantu penderita penyakit untuk sembuh dari sakit yang dideritanya dan meningkatkan kualitas hidup penderita tersebut (Stephens, O Frederick, 2009). Radiasi dapat digunakan dengan tujuan sebagai berikut yaitu:

\section{Kuratif}

Tujuannya untuk memusnahkan semua sel ganas yakni menghilangkan atau eradikasi tumor pada daerah lokal dan kelenjar getah bening regional. tujuan ini dapat dicapai pada perluasan tumor minimal atau dini tanpa ditemukan metastasis, misalnya pada karsinoma nasofaring, kanker mulut rahim.

2. Paliatif

Tujuannya untuk menghilangkan atau mengurangi gejala sehingga dapat meningkatkan kualitas hidup pasien. Diberikan pada kanker dalam stadium lanjut, baik lokal maupun dengan metastasis misalnya pada kasus keganasan keluhan nyeri karena metastasis tulang dengan ancaman fraktur dan kasus pendarahan akibat keganasan (R. Susworo, 2007). 


\subsubsection{Radioterapi Eksternal}

Radiasi eksternal/ teleteraphy, adalah bentuk pengobatan radiasi dengan sumber radiasi mempunyai jarak dengan target yang dituju atau berada diluar tubuh. Pesawat Teleterapi menggunakan source berupa radioaktif dan pancaran elektron dengan sumber listrik. Prinsip penggunaan pesawat radioterapi eksternal yakni target berada pada jarak tertentu dari source.

Alasan mendasar mengenai jarak antara source ke target adalah karena perbedaan efisiensi (jika terlalu jauh atau melebihi yang telah ditentukan maka energi yang terpancar sampai mencapai target akan membutuhkan energi yang lebih besar dan waktu yang lama), dan karena elekron kontaminasi yang berada di sekitar $50 \mathrm{~cm}$ dari source. Selama proses terapi, yakni saat posisi beam on yang ada di ruang perawatan hanya pasien saja. Para radiografer mengawasi dan mengendalikan alat dari ruang operator (Oktaviana,2016).

\subsection{Kanker Cervix}

Kanker cervix adalah jenis kanker yang muncul dari leher rahim. Kanker ini terutama disebabkan oleh pertumbuhan abnormal (atau) perubahan sel pada cervix. Pada perubahan abnormal menyebabkan beberapa gejala, yang meliputi perdarahan dari vagina, rasa sakit di perut bagian bawah, nyeri saat berhubungan seks dan keputihan. Kebanyakan kanker cervix disebabkan oleh virus yang disebut human papillomavirus (HPV). Hal ini dapat diobati dengan baik ketika itu ditemukan pada tahap awal kanker. Tes Pap yang abnormal atau tes Pap adalah tes yang lazim dilakukan sebagai bagian dari tes rutin yang dilakukan wanita. Tes ini dapat mendeteksi sel-sel pra-kanker dan kanker divagina dan leher rahim. Hal ini tidak digunakan mendeteksi jenis kanker lainnya. Tes ini diambil sebagai sampel kecil dari sel dikumpulkan dari permukaan cervix dengan sikat atau spatula. Sel-sel ini kemudian dioleskan ke slide dan diperiksa di bawah mikroskop di laboratorium untuk mengetahui pertumbuhan sel atau perubahan sel abnormal (Gregory Lee, 2014).

Cervix merupakan bagian bawah uterus (uterine cervix). cervix menghubungkan antara uterus (tempat tumbuh dan berkembangnya fetus) dengan liang vagina (jalan lahir). Bagian dari cervix yang paling dekat dengan korpus uteri disebut endocervix dan bagian yang paling dekat dengan liang vagina disebut exocervix ectocervix). Tipe sel utama yang menutupi cervix adalah sel squamous (pada exocervix) dan sel glandular (pada endocervix). Dua tipe sel tersebut bertemu pada transformation zone. Seringkali kanker cervix bermula pada daerah transformation zone (American Cancer Society, 2013).

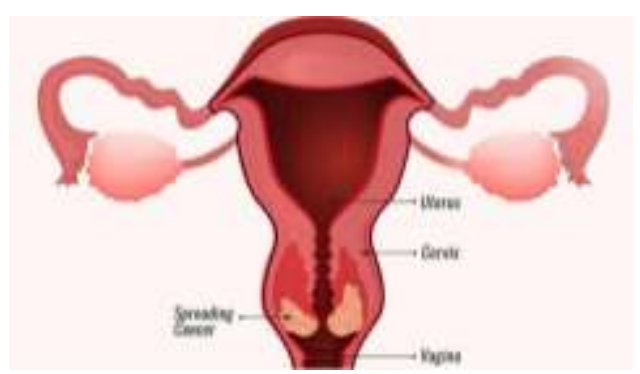

Gambar 2.2 Bagian - bagian dalam pada kelamin wanita

\subsubsection{Terapi Kanker Serviks}

Bila diagnosa histopatologik telah dibuat, maka pengobatan harus segera dilakukan dan pilihan pengobatan tergantung pada beberapa faktor yaitu:

1. Letak dan luas lesi

2. Usia dan jumlah anak serta keinginan menambah jumlah anak

3. Adanya patologi lain dalam uterus

4. Keadaan sosial ekonomi

5. Fasilitas

Pengobatan kanker serviks tergantung pada tingkatan stadium klinis. Secara umum dapat digolongkan ke dalam tiga golongan terapi (Indriyani D., 1991) yaitu:

1) Operasi

Operasi dilakukan pada stadium klinis I dan $\Pi$, meliputi histerektomi radikal, histerektomi ekstrafasial dan limpadenotomi. Pada stadium klinis $\Pi$, di samping operasi, dilakukan juga terapi radiasi untuk mengurangi risiko penyakit sentral yang terus berlanjut. 
2) Radioterapi

Terapi radiasi yaitu dengan menggunakan sinar $\mathrm{X}$ berkekuatan tinggi yang dapat dilakukan secara internal maupun eksternal. Terapi radiasi dilakukan pada Stadium klinis Ш. Selain radiasi terkadang diberikan pula kemoterapi sebagai kombinasi terapi.

\section{3) Kemoterapi}

Kemoterapi dilakukan bila terapi radiasi tidak mungkin diberikan karena metastase sudah sangat jauh. Umumnya diberikan pada Stadium klinis IV B dan hanya bersifat paliatif.

\subsection{LINAC}

Akselerator linear (linear accelerator, LINAC) adalah alat terapi radiasi yang eksternal yang paling umum digunakan untuk pasien yang terkena kanker. Linear accelerator digunakan untuk mengobati semua lokasi badan yang terkena kanker, menyampaikan high-energy sinar-x yang sama dosisnya kepada daerah tumor pasien. Alat ini digunakan tidak hanya dalam terapi radiasi eksternal, tetapi juga untuk Radiosurgery Stereotactic dan Badan Stereotactic Radioterapi yang serupa menggunakan gamma. Sinar-Rontgen ini dapat menghancurkan sel kanker selagi melingkupi jaringan normal.

Aplikasi LINAC Akselerator linier (Linear Accelerator, LINAC) pertama kali diperkenalkan oleh R. Wideroe di Swiss pada 1929, namun unjuk kerjanya saat itu kurang memuaskan. LINAC mempunyai kelebihan dan kekurangan dibandingkan dengan akselerator magnetik. Ukuran alat dan biaya yang diperlukan untuk mengoperasikan LINAC kira-kira proporsional dengan energi akhir partikel yang dipercepat. Sedang pada akselerator magnetik, tenaga yang diperlukan akan lebih tinggi untuk menghasilkan energi akhir partikel yang sama besarnya. Oleh sebab itu, untuk mendapatkan partikel berenergi sangat tinggi, LINAC akan lebih ekonomis dibandingkan akselerator magnetik. Di samping itu, penyuntikan partikel yang akan dipercepat dalam akseleratormagnetik sangat sulit dilakukan, sedang pada LINAC partikel dalam bentuk berkas terkolimasi secara otomatis terpencar kedalam tabung akselerator. LINAC dapat dipakai untuk mempercepat partikel hingga berenergi di atas $1 \mathrm{BeV}$. Betatron praktis tidak mungkin mencapai energi setinggi ini karena memerlukan magnet berukuran sangat besar

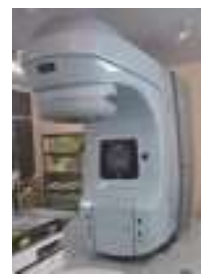

Gambar 2.3. LINAC pada Instalasi Radioterapi RSUD Dr. SOETOMO

\subsubsection{Prinsip kerja dari linear accelerator (LINAC)}

LINAC semula dipakai untuk mempercepat partikel bermuatan positif seperti proton. Namun, setelah berbagai modifikasi, mesin dapat pula dipakai untuk mempercepat partikel bermuatan negatif seperti elektron. Dalam hal ini, elektron yang dipercepat mampu bergerak dengan kecepatan mendekati kecepatan cahaya (elektron dengan energi $2 \mathrm{MeV}$ bergerak dengan kecepatan 0,98 c, dengan c adalah kecepatan cahaya). Jika elektron berenergi tinggi itu ditabrakan pada target dari logam berat maka dari pesawat LINAC akan dipancarkan sinar-X berenergi tinggi. Radioterapi dapat juga dilakukan dengan menggunakan elektron berenergi tinggi. Elektron yang dipercepat dalam LINAC dapat langsung di manfaatkan untuk radioterapi tanpa harus ditabrakan terlebih dahulu dengan logam berat. Jadi, LINAC dapat juga berperan sebagai sumber radiasi partikel berupa elektron cepat yang dapat dimanfaatkan untuk radioterapi tumor. Akselerator Linear dalam aplikasinya menggunakan teknologi gelombang mikro yang juga digunakan untuk radar. Gelombang mikro ini dimanfaatkan untuk mempercepat elektron dalam akselerator yang disebut "wave guide". LINAC menggunakan teknologi microwave (teknologi yang sama seperti yang

JBP Vol.23, No.02, Desember 2021- Winarno, Veren Audia Nurmansya, Zakiyatul Miskiyah 
digunakan dalam radar) untuk mempercepat electron digunakan suatu alat yang disebut sebagai "wave guide", hal tersebutlah yang kemudian mengizinkan elektron bertumbukan dengan heavy metal target. Hasil dari tumbukan antara elektron dan metal adalah high-energy $\mathrm{x}$-rays yang dihasilkan oleh metal target. High energy $x-$ rays tersebut kemudian akan diatur untuk kemudian diberikan pada pasien tumor dan diatur keluarannya dari mesin yang disesuaikan dengan keadaan dari pasien. Sinar yang keluar dari bagian accelerator disebut sebagai gantry yang berotasi di sekeliling pasien.

Pesawat Linac menghasilkan berkas radiasi elektron yang dipercepat atau foton $\sin a r \neg X$ bertenaga tinggi. Sebelum melakukan pengukuran output perlu diketahui berkas mana akan diukur, karena cara pengukuran kedua berkas tersebut tidak sama, dalam metode maupun peralatan yang digunakan untuk pengukuran. Sebelum dilakukan pengukuran, perlu dilakukan pengecekan energi berkas, apakah sama dengan energi berkas pada panel kontrol. Jika terdapat perbedaan maka perlu dilakukan penyesuaian energi dengan memutar tombol pengatur. Pengecekan energi foton yang dihasilkan pesawat Linac, perlu dilakukan pengukuran dosis pada kedalaman 10 dan $20 \mathrm{~cm}$ dalam fantom air. Dari hasil pengukuran ini ditetapkan nilai perbandingan D10/D20 -nya, lalu dicari energi fotonnya melalu kurva D10/D20 vs energi foton. Pasien ditempatkan pada kursi pengobatan yang dapat bergerak kesegala arah, agar dapat dipastikan pemberian radiasi dalam posisi yang tepat. Radiasi dikirim melalui kursi pengobatan. Akselerator Linear yang merupakan akselerator dengan partikel lurus mangandung unsure-unsur :

1. Sumber partikel.

Tergantung pada partikel yang sedang bergerak. Proton yang dihasilkan dalam sumber ion memiliki desain yang berbeda. Jika partikel lebih berat harus dipercepat, misalnya ion uranium.

1. Sebuah sumber tegangan tinggi untuk injeksi awal partikel.

2. Sebuah ruang hampa pipa vakum.
Jika perangkat digunakan untuk produksi sinar-X untuk pemeriksaan atau terapi pipa mungkin hanya 0,5 sampai 1,5 meter, sedangkan perangkat yang akan diinjeksi bagi sebuah sinkrotron mungkin sekitar sepuluh meter panjangnya, serta jika perangkat digunakan sebagai akselerator utama untuk investigasi partikel nuklir, mungkin beberapa ribu meter.

1. Dalam ruang, elektrik elektroda silinder terisolasi ditempatkan, yang panjangnya bervariasi dengan jarak sepanjang pipa.

Panjang elektroda ditentukan oleh frekuensi dan kekuatan sumber daya penggerak serta sifat partikel yang akan dipercepat, dengan segmen yang lebih pendek di dekat sumber dan segmen lagi dekat target.

1. Satu atau lebih sumber energi frekuensi radio, Sebuah akselerator daya yang sangat tinggi akan menggunakan satu sumber untuk elektroda masing-masing. Sumber harus beroperasi pada level daya yang tepat, frekuensi dan fase yang sesuai dengan jenis partikel dipercepat untuk mendapatkan daya perangkat maksimum.

2. Sebuah sasaran yang tepat. Pada kecepatan mendekati kecepatan cahaya, peningkatan kecepatan tambahan akan menjadi kecil, dengan energi yang muncul sebagai peningkatan massa partikel. Dalam bagian-bagian dari akselerator hal ini terjadi, panjang elektroda tabung akan hampir berjalan konstan.

3. Tambahan elemen lensa magnetis atau elektrostatik Untuk memastikan bahwa sinar tetap di tengah pipa dan elektroda nya.

4. Akselerator yang sangat panjang akan menjaga keselarasan tepat komponen mereka melalui penggunaan sistem servo dipandu oleh sinar laser.

\subsubsection{Monthly Test pada Pesawat LINAC}

Kontrol kualitas bulanan ditujukan untuk parameter-parameter yang mempunyai dampak kecil terhadap pasien, sebagai contoh: indikator jarak meja pasien (baik lateral,

JBP Vol.23, No.02, Desember 2021- Winarno, Veren Audia Nurmansya, Zakiyatul 
longitudinal, ketinggian ataupun rotasi), luas lapangan cahaya penyinaran, beam flatness, profile consistency. Selain itu, dilakukan juga verifikasi pretreatment untuk setiap kasus IMRT dengan menggunakan IBA Dosimetry MatriXX Evolution.

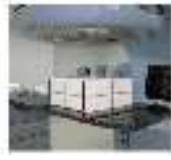

Gambar 2.3.2. Setup MatriXX

Evolution untuk verifikasi IMRT.

Dikombinasikandengan MultiCUBE

Uji Jaminan mutu bulanan ini salah satunya yaitu dengan menggunakanwater phantom yang dilakukan sebanyak satu kali dalam sebulan.Perangkat water Phantom berfungsi sebagai kalibrator untuk mengatur ulang fungsi alat scan melalui seperti semula menjadi di bawah batas toleransi. Seperangkat alat water phantom akan mendeteksi berupa keluaran dosis dari pesawat LINAC yang ditampilkan melalui elektrometer dengan satuan MU (Monitor Unit). Keluaran dari Water Phantom akan menunjukkan keluaran dari pesawat LINAC selama digunakan dengan mengacu pada nilai $1 \mathrm{cGy}$ setara dengan 1 MU. Perhitungan dosis mengacu pada TRS-398, sehingga kalibrasi alat Pesawat LINAC menggunakan Water Phantom sangat penting dilakukan agar tidak terjadi kesalahan pada tampilan dosis keluaran. Secara umum, berikut merupakan monthly test pada pesawat linac:

Tabel 2.3.2 Monthly Test pada pesawat

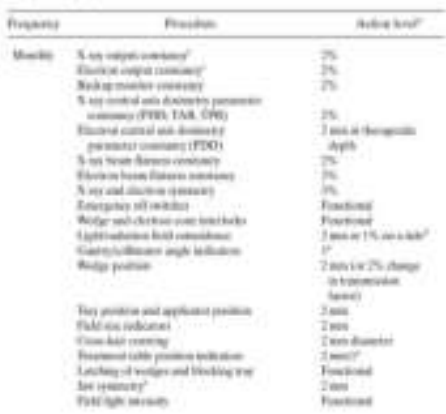

LINAC

\subsubsection{Annual Test pada Pesawat Varian LINAC}

Jika stabilitas terjaga dengan baik, maka alatpesawat LINAC masih bekerja dengan baik. Apabila diketahui keluaran dosisPesawat LINAC tidak lagi stabil, maka seorang fisikawan medis harusmelaporkan kesalahan tersebut kepada seorang teknisi alat Pesawat LINACsehinggadapat diperbaiki dan dapat bekerja dengan baik.Selain itu ada parameter lain yang pada tes tahunan,yaitu sebagai berikut:

Tabel 2.3.3 Annual Test pada pesawat LINAC

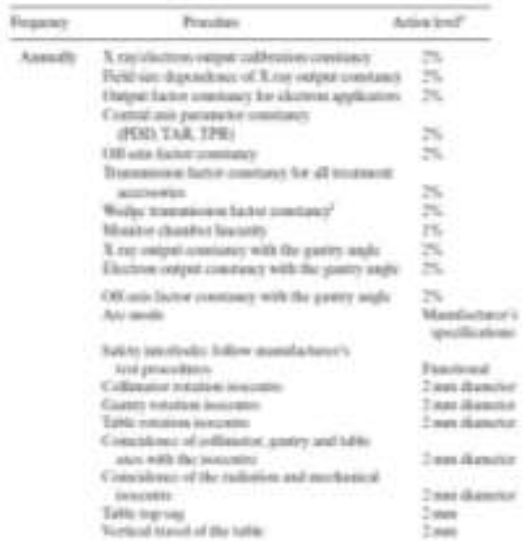

\subsection{Fisikawan Medis}

Menurut Aliansi Fisikawan Medik Indonesia, Fisika Medis adalah cabang terapan ilmu Fisika yang menggunakan prinsip, metode dan filosofi fisika dalam praktik dan penelitian untuk pencegahan, diagnosis dan pengobatan penyakit dengan tujuan meningkatkan kesehatan dan kesejahteraan masyarakat. Fisika Medis selanjutnya dapat dikelompokkan menjadi beberapa sub-bidang (spesialisasi), yakni Fisika Radioterapi, Fisika Radiologi Diagnostik dan Intervensional, dan Fisika Imajing Kedokteran Nuklir. Bidang-bidang ini juga terkait erat dengan bidang ilmu lainnya seperti Biofisika, Teknik Biomedika dan Fisika Kesehatan.

Dikutip dariAliansi Fisikawan Medik Indonesia, Fisikawan medik adalah individu profesional yang mempraktikkan

JBP Vol.23, No.02, Desember 2021- Winarno, Veren Audia Nurmansya, Zakiyatul 
ilmu Fisika Medis. Menjadi fisikawan medik memerlukan pendidikan dan pelatihan terstruktur mengenai konsep dan teknik penerapan Fisika dalam bidang medis. Fisikawan medik dapat bekerja di institusi fasilitas pelayanan kesehatan, akademik, atau penelitian. Fisikawan medik yang bekerja di lingkungan klinis adalah tenaga kesehatan yang dilindungi oleh undangundang, yang telah menjalani pelatihan pendidikan terstruktur dalam konsep dan aplikasi klinis yang kompeten untuk berpraktik secara mandiri di subbidang (spesialisasi) Fisika Medis.Ilmu Fisika Medis dan profesi fisikawan medik hadir untuk mengupayakan hal itu dengan cara melaksanakan dan mengembangkan metode penjaminan kualitas dari segi keamanan dan kelayakan peralatan radiasi medis secara utuh.

\subsubsection{Tugas Fisikawan Medis}

Fisikawan medik mengupayakan segala hal demi menekan risiko dari radiasiterhadap pasien, pekerja, dan lingkungan, serta memastikan penggunaan radiasi lebih aman dan bermutu. Secara umum, fisikawan medik mempunyai tugas:

- Problem solving mengenai penggunaan radiasi di ranah klinis dengan pendekatan ilmiah,

- Pengukuran, estimasi, dan perhitungan jumlah radiasi yang diterima pasien dan staf medis dengan metode ilmiah,

- Memastikan seluruh peralatan medis yang bekerja dengan konsep Fisika beroperasi dengan baik/aman untuk pasien, staff, dan lingkungan. Fisikawan medik memiliki program dan keahlian khusus untuk memastikan hal ini secara berkala,

- Mengoptimalkan penggunaan radiasi kepada pasien dan memastikan bahwa pasien menerima lebih banyak manfaat ketimbang efek samping,

- Edukasi dan konsultasi mengenai manfaat dan risiko radiasi serta besaran Fisika lainnya kepada kolega/sesama staf dan juga publik (termasuk pasien dan keluarganya), dan
Penelitian dan inovasi metode dan peralatan terkait penggunaan besaran Fisika di ranah medis, yang semuanya bertujuan akhir melindungi pasien, staf, dan lingkungan dari bahaya radiasi yang tidak bermanfaat.

Dari segi regulasi, pelayanan fisikawan medik di fasilitas pelayanan kesehatan diatur oleh standar layanan oleh Menteri Kesehatan RI (Permenkes 83 Tahun 2015).

\section{METODE RADIOTERAPI CA- CERVIX MENGGUNAKAN LINAC}

Penyinaran radioterapi untuk $\mathrm{Ca}-$ Serviks adalah menggunakan teknik konformal 3 dimensi. Menggunakan dosis sebesar 20 Gy dalam 10 fraksinasi. Dengan melakukan deliniasi pada seluruh uterus dan vagina serta organ at risk seperti kandung kemih dan rektum.

Perencanaan radiasi konformal 3 dimensi dilakukan dengan cara memasang penanda logam pada sentrasi radiasi. Potongan CT dibuat dari vertebrae lumbal 5 sampai bawah tulang ischium. Gantry CTpada posisi $0^{\circ}$. Ketebalan irisan CT adalah $3 \mathrm{~mm}$, interval antar irisan $5 \mathrm{~mm}$. Semua catatan CT direkam dalam kepingan VCD oleh sistem DICOM. Fisikawan medis membuat 5-7 berkas sinar (beam) dari arah gantry yang berbeda.

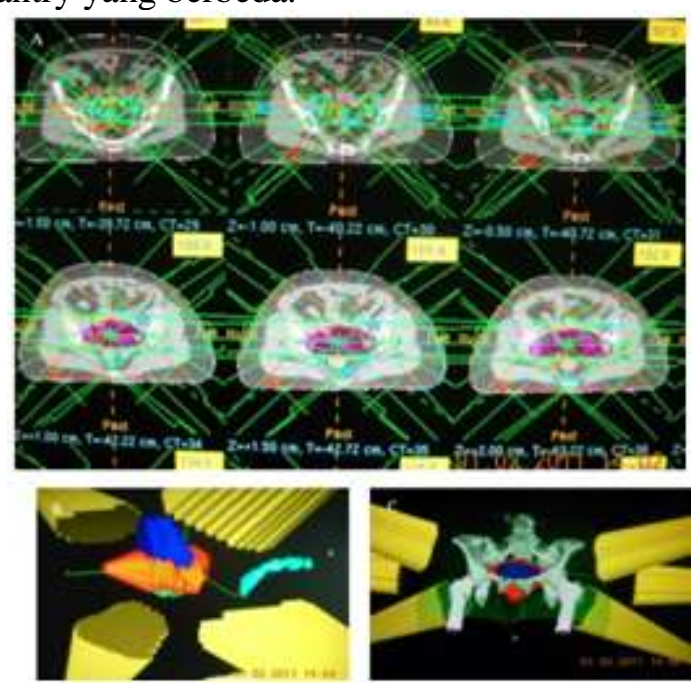

Gambar 3. Penyinaran Ca-Cervix Teknik Konformal 3D

\section{HASIL DAN PEMBAHASAN}


Treatment Planning System pada Pesawat Linac menggunakan software Eclips 13,6. beberapa data untuk planning diatur menggunakan software ini, termasuk posisi pasien, energi yang digunakan (foton atau elektron), waktu penyinaran, dosis dan fraksi radiasi, jumlah field, sudut gantry, hingga mengatur MLC. Semua yang diatur pada software eclips 13.6 sudah otomatis terhubung dengan komputer pada operator LINAC, sehingga nantinya radiografer bisa langsung mengoprasikan LINAC sesuai ketentuan yang sudah diatur dalam software, tentunya juga butuh pengawasan oleh Fisikawan Medis.

beberapa ketentuan untuk radioterapi caserviks diantaranya:

- Jumlah field untuk radioterapi CaServiks adalah 4 field, dengan sudut masing-masing adalah $0^{\circ}, 90^{\circ}, 180^{\circ}$ dan $270^{\circ}$.

- Dosis radiasi 20 Gy dalam 10 fraksinasi.

- Energi radiasi berupa foton. Umumnya LINAC memancarkan foton atau elektron dengan energi sebesar $6 \mathrm{MeV}$ atau $10 \mathrm{MeV}$. Prinsip kerja linac yaitu mempercepat elektron sehingga energi kinetiknya bertambah dari $4 \mathrm{MeV}$ menjadi 25 $\mathrm{MeV}$.

- MLC diatur hingga semua sasaran tercover dan melindungi organ sehat atau OAR yang disekitarnya.

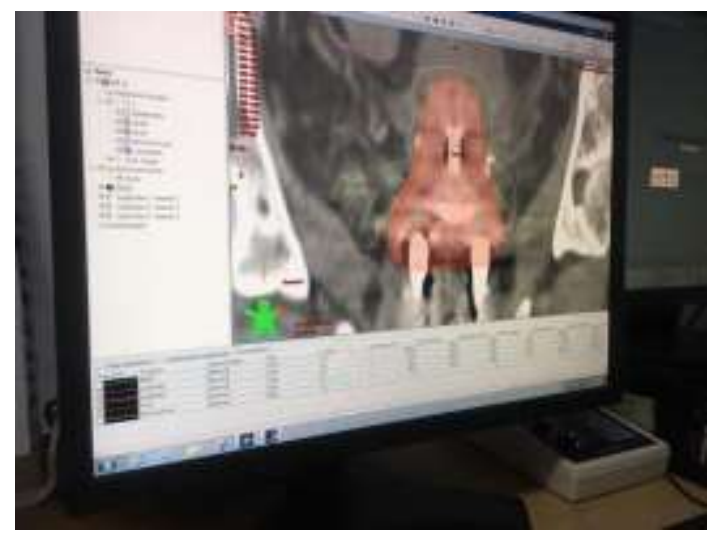

Gambar 4.1.a. Perencanaan TPS pada Ca serviks tampak depan

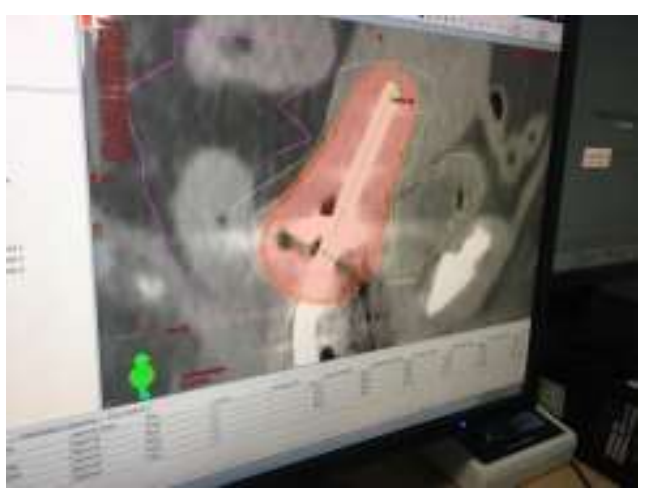

Gambar 4.1.b. Perencanaan TPS pada Ca serviks tampak Samping.

Setelah itu, fisikawan medis dapat melakukan simulasi terhadap pasien penderita kanker serviks untuk mengetahui batas-batas radiasi yang merupakan duplikat dari pelaksanaan radiasi yang akan dilakukan. Dalam melakukan simulasi ini menggunakan stimulator dimana alat ini berfungsi untuk menampilkan gambaran organ dalam yang akan terkena sinar. Kemudian melakukan pembuatan blok untuk menutupi organ organ sehat atau biasa disebut organ at risk (OAR) yang berada di sekitar kanker atau tumor sehingga jaringan yang ditutupi oleh blok tidak rusak saat menerima dosis penyinaran. Pembuatan blok ini sengan cara menghitung dosis radiasi dan depth dose yang diberikan dokter beserta luasan dari hasil simulasi sehingga nantinya akan menghasilkan luasan daerah yang akan diradiasi.

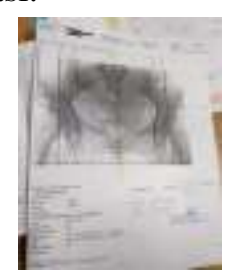

Gambar 4.3 Hasil Simulasi dan pemberian TD dan DD oleh dokter 
Untuk mencari luasan paparan radiasi dilakukan perhitungan sebagai berikut :

* Diketahui dari hasil simulasi :

- $\operatorname{sumbu} \mathrm{x}_{1}=8, \mathrm{x}_{2}=8, \mathrm{y}_{1}=9,5 ; \mathrm{y}_{2}=$ 9,5 (dari blok segitiga yang telah di gambar oleh dokter dan skala yang digunakan)

- $\quad$ alas $=2$

- $\quad$ tinggi $=9,5$

maka utuk mengetahui luasannya yaitu dengan mengurangkan luas persegi panjang dan luas 4 segitiga yang terbentuk dan mengakar hasilnya

$$
\begin{aligned}
\mathrm{L} & =\mathrm{p} \times 1 \\
& =16 \times 19 \\
& =304
\end{aligned}
$$$$
\mathrm{L} \Delta=(1 / 2 \mathrm{x} \text { alas } \mathrm{x} \text { tinggi }) 4
$$

Dikali 4 karena ada 4 segitiga

$$
\begin{aligned}
& =1 / 29,5 \cdot 2 \cdot 4 \\
& =38
\end{aligned}
$$$$
\mathrm{L} \quad=304-38
$$$$
=266
$$$$
=\sqrt{266}
$$$$
=16,3
$$

Dari hasil 16,3 maka luasan dibulatkan menjadi $16 \times 16$.

Biasanya perhitungan dosis pada kanker serviks telah dihitung oleh dokter spesialis onkologi sebesar 25 × 2 Gy yang artinya 25 kali penyinaran, setiap penyinaran 2Gy. Namun, seorang fisikawan medis juga dapat melakukan perhitungan dosis dengan menggunakan rumusan :

- Metode SSD (Source Surface Distance)

Time $=\mathrm{TD}$

$$
\text { DR x PDD x FF x WF x W }
$$

- Metode SAD (Source Axis Distance)

Time $=$ TD

\section{TAR x DR x FF $x$ WF $x$ W}

Dimana :

$\mathrm{TD}=$ tumor dosis

$\mathrm{WF}=$ weighting Field

$\mathrm{FF}=$ Field Factor

$\mathrm{DR}=$ Dose rate

$\mathrm{W}=$ Weight

TAR $=$ Tissue Air Ratio

PDD $=$ persentafe Depth Dose
Dilakukan penyinaran Untuk mendapatkan waktu lama penyinaran terapi, menggunakan rumus :

$$
\mathrm{t} \mathrm{AP} / \mathrm{PA}=\frac{\text { dose }}{\text { TAR } \mathrm{x} \text { laju dosis }}
$$

\section{Dimana}

- Nilai TAR sebesar 0.8190

- Dosis 2 Gy : $2=1$ Gy $=100 \mathrm{cGy}$ (dosis dibagi dua karena menggunakan teknik penyinaran SSD sehingga ada 2 lapangan yang di radiasi yaitu pada sudut $0^{\circ}$ dan $180^{\circ}$ )

- Untuk luas lapangan 16 x 16 laju dosisnya $=149,72$

Maka untuk menentukan waktunya dengan menyubstitusi pada rumus $t A p / P A$

$$
\begin{aligned}
\mathrm{t} \mathrm{AP} / \mathrm{PA} & =\frac{\text { dose }}{\mathrm{TAR} \times \text { laju dosis }} \\
\mathrm{t} \mathrm{AP} / \mathrm{PA} & =\frac{100}{0.8190 \times 149.72} \\
& =0.815 \text { menit }
\end{aligned}
$$

Setelah didapatkan waktu lamanya penyinaran, proses perhitungan telah disetujui oleh dokter, dan kertas jaminan mutu spesifik pasien telah dilengkapi isinya maka dapat dilakukan penyinaran yang sesungguhnya.

\section{KESIMPULAN DAN SARAN}

\section{Kesimpulan}

Fisikawan Medis memiliki peranan penting dalam proses radioterapi, diantaranya melakukan treatment planning system pasien radioterapi bersama dokter, melakukan simulasi terhadap pasien kemudian membuat block untuk melindungi organ sehat. Setalah itu, melakukan perhitungan dosis radiasi pada tumor dan menganalisis waktu lamanya penyinaran radiasi terhadap sel tumor.

\section{Saran}

Dalam melakukan observasi penelitian atau dalam melakukan praktik kerja lapangan (PKL) praktikan harus lebih teliti dalam observasi objek penelitian, agar tujuan dari praktik kerja

JBP Vol.23, No.02, Desember 2021- Winarno, Veren Audia Nurmansya, Zakiyatul Miskiyah 
lapangan dapat terlaksan dengan baik dan menyeluruh. Menjaga etika dalam berinteraksi terutama dengan pasien agar tidak menyinggung privasi pasien serta menaati peraturan dan kebijakan yang telah ditetapkan oleh Rumah Sakit.

\section{UCAPAN TERIMA KASIH}

Penulisan laporan ini tidak lepas dari bantuan berbagai pihak. Untuk itu menyampaikan ucapan terima kasih kepada:

1. Tuhan Yang Maha Esa atas segala rahmat dan hidayah-Nya sehingga penulis dapat menyelesaikan penyusun jurnal ini.

2. Orang tua dan keluarga penulis yang selalu memberikan kasih sayang dan dukungan yang tiada henti.

3. Prof. Dr. Moh. Yasin.

M. Si selaku ketua departemen Fisika Fakultas Sains dan Teknologi Universitas Airlangga.

4. Dr. Suryani Dyah Astuti, M.Si selaku dosen pembina PKL di program studi S1 Fisika Fakultas Sains dan Teknologi Universitas Airlangga.

5. dr. Dyah Erawati., Sp.Rad (K) Onk. Rad selaku kepala Instalasi Radioterapi RSUD Dr. Soetomo surabaya.

6. Bambang Haris Suhartono, M.Si., FM., Sp. RT selaku pembimbing PKL di RSUD dr. Soetomo Surabaya.

7. Staff fisika medis RSUD Dr. Soetomo Surabaya

8. Staff radiographer Instalasi Radioterapi RSUD Dr. Soetomo
Surabaya.

9. Seluruh karyawan serta staff Instalasi Radioterapi RSUD Dr. Soetomo Surabaya.

10. Staff bagian pendidikan dan latihan di RSUD Dr. Soetomo Surabaya yang membantu dalam penyelenggaraan PKL.

11. Semua pihak yang telah membantu, tidak dapat kami sebutkan satu persatu. Kami menyadari masih terdapat kekurangan dalam penulisan laporan ini.

Oleh karena itu kritik dan saran yang sifatnya membangun sangat diharapkan demi memperbaiki laporan agar lebih baik. Kami berharap agar laporan ini bermanfaat. Terima kasih.

\section{ACUAN REFERENSI}

Sifat dari radiasi pengion dapat merusak jaringan, maka diusahakan dosis radiasi yang diberikan pada sel tumor harus terdistribusi secara merata atau homogen sesuai dengan aturan International Commision on Radiation Unit (ICRU) yaitu dosis maksimum dalam rentang $95 \%-100 \%$ (Syam, 2012).

Prinsip radioterapi adalah memberikan dosis radiasi yang mematikan tumor pada daerah yang telah ditentukan (volume target) sedangkan jaringan normal sekitarnya mendapat dosis seminimal mungkin. Hal ini sangat ditunjang dengan kemajuan teknologi dari alat-alat radioterapi dan kemajuan dari komputer. Perkembangan teknologi di dunia kedokteran tidak dapat dipungkiri telah membantu penderita penyakit untuk sembuh dari sakit yang dideritanya dan meningkatkan kualitas hidup penderita tersebut (Stephens, O Frederick, 2009).

Tujuan radiasi untuk menghilangkan atau mengurangi gejala sehingga dapat meningkatkan kualitas hidup pasien. Diberikan pada kanker dalam stadium lanjut, baik lokal maupun dengan metastasis misalnya pada kasus keganasan keluhan nyeri karena metastasis tulang dengan ancaman fraktur dan kasus pendarahan akibat keganasan (R. Susworo, 2007). 
Alasan mendasar mengenai jarak antara source ke target adalah karena perbedaan efisiensi (jika terlalu jauh atau melebihi yang telah ditentukan maka energi yang terpancar sampai mencapai target akan membutuhkan energi yang lebih besar dan waktu yang lama), dan karena elekron kontaminasi yang berada di sekitar $50 \mathrm{~cm}$ dari source. Selama proses terapi, yakni saat posisi beam on yang ada di ruang perawatan hanya pasien saja. Para radiografer mengawasi dan mengendalikan alat dari ruang operator (Oktaviana,2016).

Tes Pap yang abnormal atau tes Pap adalah tes yang lazim dilakukan sebagai bagian dari tes rutin yang dilakukan wanita. Tes ini dapat mendeteksi sel-sel pra-kanker dan kanker divagina dan leher rahim. Hal ini tidak digunakan mendeteksi jenis kanker lainnya. Tes ini diambil sebagai sampel kecil dari sel dikumpulkan dari permukaan cervix dengan sikat atau spatula. Sel-sel ini kemudian dioleskan ke slide dan diperiksa di bawah mikroskop di laboratorium untuk mengetahui pertumbuhan sel atau perubahan sel abnormal (Gregory Lee, 2014).

Cervix merupakan bagian bawah uterus (uterine cervix). cervix menghubungkan antara uterus (tempat tumbuh dan berkembangnya fetus) dengan liang vagina (jalan lahir). Bagian dari cervix yang paling dekat dengan korpus uteri disebut endocervix dan bagian yang paling dekat dengan liang vagina disebut exocervix ectocervix). Tipe sel utama yang menutupi cervix adalah sel squamous (pada exocervix) dan sel glandular (pada endocervix). Dua tipe sel tersebut bertemu pada transformation zone. Seringkali kanker cervix bermula pada daerah transformation zone (American Cancer Society, 2013).

\section{DAFTAR PUSTAKA}

Bentel. 1996. Radiation Treatmen Planning. USA : McGraw-Hill.

Cember, H., 1980. Introduction toHealth Physics. New York : Pergamon Press Inc.
Darmawati dan Suharni, 2012, Implementasi Linear Accelerator dalam Penanganan Kasus Kanker, Prosiding Pertemuan dan Presentasi Ilmiah Teknologi Akselerator dan Aplikasinya, Yogyakarta.

Dr. Irwan Kreshnamurti dkk. Radioterapi Pada Kanker Serviks. Semarang. Universitas Sriwijaya.

I. G. S. Dharmawan. 2006. Visualisasi penentuan waktu penyinaran harian kanker untuk tekniks.s.d.

PERMENKES. 2015 . Peraturan Menteri Kesehatan No. 83 pasal 1: (3) dan (2). Indonesia

Podgorsak, E.B. 2005. Radiation Oncology Physics: A Handbook for Teachers and Students. Austria: International Atomic Energy Agency. 